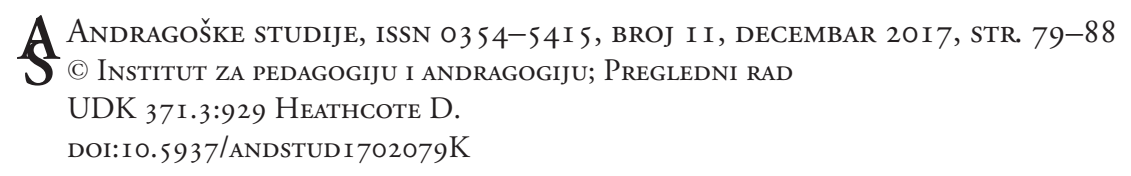

\author{
Amanda Kipling ${ }^{1}$ \\ Goldsmiths, University of London, UK
}

\title{
The Praxis of Dorothy Heathcote: A Paradigm in its own Right?
}

\begin{abstract}
This paper explores the praxis of Dorothy Heathcote as a paradigm in its own right, making strong links with the work of Paolo Freire, Carl Rogers and Augusto Boal. Having provided this background I consider in particular Heathcote's last model - Rolling Role. I then explore how by adopting this paradigm, her praxis engages learners into a practice which is also a paradigm in its own right, allowing them to engage in their own research into themselves and their own learning.
\end{abstract}

Key Words: Dorothy Heathcote, Drama education, Rolling Role, teacher paradigm, pupil paradigm, phronesis.

\section{Introduction}

As described by Wagner (1976) and later by Bolton (1998), Heathcote was the first Drama pioneer to sit on the floor with her learners and 'make a play' with them. This is well demonstrated in the television documentary Three Looms Waiting (Smedley, 1971).

As 'Teacher in Role' - Heathcote would be involved the Drama with the learners and steering the work from within by planting a source, letter or problem into the Drama. This resulted in and model she called 'Man in a Mess'. Heathcote would withdraw from the drama and let the learners engage in resolving

\footnotetext{
${ }^{1}$ Amanda Kipling is Senior Lecturer, having led the PGCE course in Drama for ten years at Goldsmiths, University of London, UK (a.kipling@gold.ac.uk).

${ }^{2}$ Training as a drama teacher during the 1980s in London I had a very child-centred initial teacher education. This was focused heavily on the work of Dorothy Heathcote, educational drama pioneer. Her practice remains the basis of all later developments in educational drama and enjoys wide-ranging influences within and beyond learning settings, being used currently in industry and business as well as in prisons, the health service, community work and higher education. It is important to acknowledge that this paper draws heavily from an assignment written as part of my studies on the EdD course at Chester in 2017. The theoretical principles of Heathcote's work are universal regardless of the group's age, nature, or setting and, therefore, the paper should be of interest and value to those engaged in education in a variety of contexts.
} 
life's problems on their own. Another model grew from this one: 'Mantle of the Expert'. Here, Heathcote played a role within the drama of the unknowing, the innocent, forgetful or unable. This leaves only the role of the expert vacant for the learners to adopt. This was in sharp contrast to the more traditional Speech and Drama of most classrooms. Heathcote's practice brought more challenging cognitive, social and creative development into the learning which was both emancipatory and empowering (Bolton, 1998).

After the war, Heathcote (1926-2011) found herself in a movement of progressive thinking in education. The context had been well-prepared by key forerunning thinkers like Jean Piaget (1896-1980) Carl Rogers (1902-1987), and Jerome Bruner (1915-2016). Meanwhile two contemporary minds were thinking along similar lines in Brazil. Paolo Freire (1921-1997) was working on his book Pedagogy of the Oppressed (Freire, 1970) while theatre practitioner Augusto Boal (1931-2009) was exploring emancipatory Forum Theatre in his book Theatre of the Oppressed (Boal, 1979). Heathcote was working within a movement of similar thinking in associated fields of education and theatre.

\section{Truth}

In the 1970s the view that research's role was to uncover absolute truth was being challenged by the more involved world of education which was finding traditional empirical research models inappropriate for the field. Bernstein's view, it resulted in 'sheer chaos' (Sparkes, 1992, p. 9). Heathcote was teaching at this time of new, innovative educational thinking and this was provoking a dilemma in research thinking.

I now use a structure from Burrell and Morgan to describe four underlying assumptions in modern research as cited by Cohen, Manion and Morrison (2011). This will illuminate Heathcote's praxis and demonstrate that her praxis embraced the qualities deemed necessary to be accepted as a paradigm in its own right.

For Smith, this idea that truth can exist 'independent of the interpreter, awaiting accurate depiction, fails to account for ontological condition of understanding our mode of being in the world' (Smith 1993, p. 152). Similarly, Nelson (2013) cites Etherington, who explains:

'...reality is socially and personally constructed; there is no fixed or unchanging Truth' (Etherington as cited in Nelson, 2013, p. 55). 
There was a great sea change taking place in education with the state sector engaging in emancipatory thinking and practices making state learning settings agents of change, and profiling the role their learners had to play in society as citizens with strengths to offer. Learning settings rejected, for a while, the forerunning trajectory towards emulating the curriculum of the private sector, which tended to reproduce the status quo rather than hand responsibility for moving society forwards to the state educated population (Wrigley, 2014).

In addition, in 1986, Carr and Kemmis asserted that seeking a single positivist truth in the educational context is inappropriate as this has 'created the illusion of an objective reality over which the individual has no control, and hence to a decline in the capacity of individuals to reflect upon their own situations and change them through their actions' (Carr and Kemmis as cited by Neelands, 2006, p. 23).

Heathcote's empowering and emancipatory classroom resonates with the vision of Carr and Kemmis very well (Freire, 1970). Against the backdrop of such creative and groundbreaking classroom practice, research needed to develop new thinking to empower itself to function in this rapidly developing field.

Eisner (1992) was thinking along similar lines and suggested that the quest for ontological truth is based on a 'correspondence of truth'. That is, a dialogue between the perceived and the perceiver. Eisner proposed that this is where the focus should lie when researching in the social sciences.

I believe we are better served by recognizing that whatever it is we think we know is a function of a transaction between the qualities of the world we cannot know in their pure, non-mediated form, and the frames of reference, personal skills, and individual histories we bring to them. (Eisner, 1992, p. 13)

It is easy to see the thinking of key figures all working in broadly the same period, coming together in the Heathcote classroom. Heathcote perceives the dramatic journey as carrying the learning as the group of learners works in a developmental and organic, socially constructed and deconstructed, fluid and unceasing way. Her form of educational drama focused on the correspondence of truth rather than seeking a truth in itself.

Using Cohen, Manion and Morrison's (2011) model, this situates Heathcote's position as internal-idealist and relativist as it is expected that multiple 'truths' will be made and processed through complex social interaction. However, it also features some qualities of critical theory as it seeks to empower and emancipate learners by placing this process in the hands of learners. 
The learners put new learning to the test immediately while within the drama: 'But if you do that, so and so will happen...', ' well let's try and see what happens...', 'That won't work because...' It is tested by and though the drama. Heathcote's learners are, researching themselves and their knowledge-making processes. They become self-knowing about what they believe they know and how they have come to believe they know it.

\section{Knowledge}

The whole matter of knowledge and what it is becomes pertinent at this stage. Gottlieb explains that Socrates, according to Plato, maintained that he refined thinking - but didn't actually know anything (Gottlieb, 2000). The drama classroom returns to reconsider this notion within Heathcote practice and falls into line with what Elliot describes as a time when 'Education ... is viewed as a dialectical process in which the meaning and significance of structures are reconstructed in the historically conditioned consciousness of individuals as they try to make sense of their 'life situations'. The mind 'adapts with' rather than 'adapts to' structures of knowledge' (Elliott, 1991, p. 10).

Thus, the notion of knowledge becomes interesting in Heathcote's practice. Returning briefly to the earliest thinkers on this matter, Socrates, according to Plato - did not purport to know anything. Rather, his interest lay in refining logical thinking, which has already been demonstrated to happen within a drama classroom with or without the teacher in role. Socrates preferred to '..let us follow the argument where it leads..' (Gottlieb, 2001, p. 27). Socrates also felt that belief processed by reasoning can become knowledge. Again, in the drama educational activities, the 'make believe ' of the situation is the belief and by working through it, learners arrive at truths - however temporary they maybe. Consequently they learn to live and work with the idea of 'truth for now'. With themselves and their other selves in role, and through these multi-layered correspondences of truth, these beliefs may transform and become knowledge.

Neelands (2006), explains that in the Aristotelian conception of the practical arts, knowledge is uncertain and incomplete, theory is based in reflection and the concrete evidence of praxis leads to phronosis; a prudent and ethical understanding of what should be done in practical situations' (Neelands, 2006, p. 25).

In this double-layered classrooms of selves, complex phronosic journeys are taking place. Truths and knowledge are subjected to 'falsification' tests, the results of which illuminate previous truths and inform the forging of new ones. 
(For example, the prisoners of war agree that they all need each other in the camp and to trust each other and work as a team to escape. Then one turns informer.) This resonates strongly with the notion Popper developed in 1935 (McNeill and Chapman, 2005) asserting that knowledge only exists till it is disproved. Great theatre shows this in action. One is put in mind of Hamlet as a strong example of how we go to see theatre in order to witness another in role as an alter ego of oneself going through this process. We, from the safety of our seats and with the space and security of suspended disbelief, follow and share the same process from another dynamic, contributing from within to ourselves.

Heathcote was ease with the idea that knowledge and truths were fluid and incomplete in her classroom, preferring to focus on meaning making, learning and the development of understanding rather than absorption of banked material (Lather, 1993). In drama there is no 'end point' of arriving at ultimate truth and, accepting this, she was released to explore the underlying workings of learning and to help learners access insight into these as well. This is empowering the learner to be skilled and understanding of their own learning journeys (Heathcote and Bolton, 1996).

Considering the notion of 'cultural capital' (Bourdieu, 1986) any drama class starts with the group building the work together from scratch - consequently all the learners start with the same co-created cultural capital. They are not trying to digest someone else's capital or need to have someone else's capital in order to start the drama (for example, there is no need for them to have learnt lines written by a playwright for homework.) The Vygotskian 'more knowledgeable other' (MKO) (Vygotsky, 1978) is a peer, not a teacher; a co-worker who is working alongside others creating the capital, and therefore interfacing with it at the same time. The MKO needs to be someone who sees things differently - not someone 'brighter' or with more capital. This transforms the nature of valued learning in the classroom from the mainstream thinking emphasis on intellectual hierarchical structures.

Leonard and Sensiper would agree that we hold undiscovered knowing in the body 'tacitly', existing on a spectrum whereby it becomes 'explicit' as it journeys through to the conscious mind. Nelson connects this with the thinking of Polyani, who suggests that by illuminating the way the body 'knows', we can access the bodily roots of all thought' and recognises both ends of this tacit/explicit spectrum as a form of knowing (Nelson, 2013, pp. 38-39). In the Heathcote classroom, I would argue that this spectrum changes to a cycle and that 'tacit knowing' journeys through 'knowing how', 'knowing that' and 'knowing what' stages (as developed by Schon, 1983) towards becoming explicit. Harnessing the concepts of Foucault, this is achieved through an exchange of discourses and the 
hermeneutics of those discourses (Veyne, 2010). Once made explicit 'knowing' becomes ripe for challenge by the new implicit knowing which is emerging.

Consequently, a complex, rhizomatic (Deleuze and Guattari as cited in Lather, 1993) living, pulsing, changing shared structure of meaning making is built. It exists on two levels as the self and the in-role 'other'. Drama - an animated rhizome - works its way towards a consensus, and a temporary functional knowledge is reached. ('There is only one solution (for now!): we will try to escape/ trick the guards...') The next quest for truth and knowledge is identified and pursued.

The Heathcote classroom is a rich epistemological space. She has created this dynamic of learning whereby her learners, having built and worked the rhizome through which they are travelling, are at once engaged on researching the microcosm of the drama and how it relates to the macrocosm of the wider world. They are two-tier co- enthnographers; as themselves and in role.

The learners will have points where they will have to agree on a matter - and find out later it is flawed. There are still truths within this situation and Hammersley warns against dismissing the value of consensus, shared resonance or agreement in research. It is often all we have in order to move on. It is by making a flawed move and by looking back from that point that clarity may be gained. Drama engages precisely in this space (Hammersley, 1992).

Thus we find that while it is deemed inappropriate to identify an ontological truth we find ourselves in the same position over knowledge. Knowledge is just as incomplete and temporary and so it is of more value to engage in conversations (Smith, 1993) and arrive at points of choral resonance in line with Hammersley's models of relevance and validity (Hammersley, 1992).

The third assumption regards human nature and Heathcote's view is essentially voluntaristic: people are in control of their lives and actively involved in creating their environment'. They are 'the controllers and not the controlled and there is a sense of agency, autonomy, and free will' (Sparkes, 1992, p 13).

\section{Methodology}

When operating outside the Drama, as Heathcote might in 'Man in a Mess' mode, one could perceive her stance as an action researcher. She worked as a coconstructor of understandings and functioned from within the lesson - though not the drama -to improve the learners' empowerment as they strive to resolve their own issues. However, if in role herself the dynamic changed and she could be more accurately described as a co-ethnographer - especially in 'Mantle of the 
Expert' where she entered into a world the learners created with them as an equal and worked to help them refine and deepen their thinking in a broadly Socratic manner from within the drama. She was experiencing them as they were experiencing themselves. This brings us towards a mixed approach which is hermeneutic, dialectic and ideographic.

In order to complete the paradigm regarding the collection of data and the manner in which this takes place in the Heathcote approach, a consideration of one last model of her practice is required to illuminate this aspect of her practice.

'Rolling Role' is Heathcote's last model, which she was still developing at the time of her death in 2011. Here, the stimulus for a lesson is provided by the previous learning group's learning experience. The teacher has a class and some material and makes a learning activity structure in response to what the learners are producing. In this model, learners provide educational nutrients not only for each other, but for other learning groups external to their immediate drama. Groups work now with an additional dynamic; with a growing sense of responsibility and respect for what they have done with the work left behind for them by the previous group and for what they will leave behind for others. They consciously wish to produce quality data as a way of being part of the creativity of the work of another group and feel some ownership of their work as integral to their own. The teacher becomes the facilitator of this process across groups. Therefore, both learning groups and teacher process data and respond to it either in or out of role and the teacher responds to it by task setting, challenging or adding new information, which makes a symbiotic creative co-processing of data which explores and informs both teaching and learning. There is no stopping to collect and process data; it is integral to the creative learning process for both teacher and learners.

I would argue that, in this model, the drama practitioner does gather data but in a very fast, fluid, instinctive way, operating from within the rhizome and outside of it at the same time. The drama practitioner processes and interfaces with the flow of data on a cognitive level and, if in role, engages with it dramatically as well.

\section{Conclusion}

Heathcote's praxis meets the required terms for being a paradigm in its own right. In addition, by default, it places her learners in a related paradigm deepening learning, understanding and meaning making. Engaging in this paradigm also 
informs teacher and learners alike about themselves and how they learn which is emancipatory and empowering.

Fundamental questions about who is selecting the material and why, the real life-purpose of the teaching beyond the subject matter and examination syllabus, the deep cognitive pathways being developed through the brain, need to be interrogated. Classroom educators, feeling manacled by the neoliberal education setting and its emphasis on examination results, could, by embracing a research paradigm informed by Heathcote practice, dramatically change the nature of their learning spaces and how they operate within them. Heathcote's models are very useful in assisting teachers of all subject disciplines on this journey. Indeed, her work has been used widely in industry, business in prison work as well as education.

Heathcote was always somewhat bemused by her following of teachers and was more interested in their developing practice in their own learning spaces rather than learning how to copy her own styles and models. In typical Socratic style, others like Wagner (1976) and Bolton (1998) wrote and analysed her work, while she wrote little preferring to pursue her own ideas and those of others.

Returning to an idea expressed earlier by Neelands, a consideration of 'phronosis; a prudent and ethical understanding of what should be done in practical situations', is required to bring this matter back to the heart of educational debates. (Neelands, 2006, p. 25). By adopting a paradigmatic lens based on Heathcote's praxis, teachers could position themselves - and their learners more strongly in their classrooms to release richer teaching and learning and truly emancipate and empower the inner learner. Re-dignifying the classroom, teachers and learners alike, the resultant pedagogy transcends the product-based demands of the educational market place. The discovery of new learning about the learning self (personalized research) could be placed in the hands of creative enquiring learners (teachers and learners of all ages), and return it to its natural home - the learning space itself.

\section{References}

Boal, A. (1979). Theater of the Oppressed. London, United Kingdom: Pluto Press. Bolton, G. (1998). Acting in Classroom Drama - critical analysis. Stoke-on-Trent, United Kingdom: Trentham.

BRuner, J. (1966). Toward a Theory of Instruction. Cambridge, MA: Harvard University Press. 
Cohen, L., Manion, L., \& Morrison, K. (2011). Research Methods in Education, London, United Kingdom: Routledge ( $6^{\text {th }}$ edition).

EIsner, E. (1992). Objectivity in Educational Research. Curriculum Inquiry, 2(1), 9-15.

Elliott, J. (1991). Action Research for Educational Change. Milton Keynes, United Kingdom: Open University Press.

Freire, P. (1970). Pedagogy of the Oppressed, London, UK: Penguin.

Gottleib, A. (2001). Socrates. In R. Monk and F. Raphael (eds), The Great Philosophers (pp. 7-46). London, United Kingdom: Phoenix.

Hammersley, M. (1992). What's Wrong with Ethnography? London, United Kingdom: Routledge.

Lather, P. (1993). Fertile Obsession: Validity After Poststructuralism. The Sociology Quarterly, 3(4), 673-693.

McNeill, P. \& Chapman, S. (2005). Research Methods. Abingdon, United Kingdom: Routledge.

Neelands, J. (2006). Reimagining the Reflective Practitioner: towards a philosophy of critical praxis. In J. Ackroyd (ed), Research Methodologies for Drama Education (pp. 15-39). Stoke-on-Trent, United Kingdom: Trentham Books.

Nelson, R. (2013). Practice as Research in the Arts: Principles, Protocols, Pedagogies, Resistance. London, United Kingdom: Palgrave Macmillan.

Piaget, J. (1970). Science of Education and the Psychology of the Child. London, United Kingdom: Penguin Books

Rogers, C. (1967). On becoming a Person. London, United Kingdom: Constable.

Schon, D. (1983). The Reflective Practitioner. New York, NY: Basic Book/Perseus.

Smedley, R. (Director) (1971). Three Looms Waiting. BBC Omnibus documentary, London. Retrieved March 16th 2017 from https://www.youtube.com/ watch?v=owKiUO99qrw

Smith, J. K. (1993). The Problem of Criteria. In J. K. Smith (Ed), After the Demise of Empiricism: the Problem of Judging Social and Educational Inquiry (pp. 147-163). New Jersey: Ablex: Norwood.

Sparkes, A. C. (1992). The Paradigm Debate: An Extended review and a Celebration of Difference. In A. C. Sparkes (Ed.), Research in Physical Education and Sport (pp 9-60). London, United Kingdom: Falmer.

Veyne, P. (2010). Foucault His Thought, His Character. Cambridge, United Kingdom: Polity Press.

Vygotsky, L. (1978). Mind in Society. Cambridge, MA: Harvard University Press. Original work published in 1930 .

Wagner, B. J. (1976). Dorothy Heathcote: Drama as a Learning Medium. Washington DC.: National Education Association

Wrigley, T. (2014). The Politics of Curriculum in Learning settings. London, United Kingdom: Centre for Labour and Social Studies. 
Amanda Kipling ${ }^{3}$

Goldsmiths, Univerzitet u Londonu, UK

\section{Praksis Doriti Hetkot kao obrazovna paradigma}

Apstrakt: Ovaj rad istražuje praksis Doroti Hetkot kao posebnu obrazovnu paradigmu oslanjajući se na rad Paola Freirea, Karla Rodžersa i Augusto Boala. Posebno sam se osvrnula na poslednji model Doroti Hetkot - Kotrljajuća uloga (Rolling Role). Nakon toga sam ispitala kako njen praksis uključuje učenike u aktivnost koja je sama po sebi paradigma, omogućujući im da se angažuju u proces samoistraživanja i sopstevnog učenja.

Ključne reči: Doroti Hetkot, dramsko obrazovanje, Rolling Role, nastavnička paradigma, učenička paradigma, phronesis.

\footnotetext{
${ }^{3}$ Amanda Kipling je viši predavač i rukovodilac PGCE kursa drame na Goldsmitu, Univerzitet u Londonu, UK.
} 